\title{
Thyroid hormone modulates $\mathrm{CIC}-2$ chloride channel gene expression in rat renal proximal tubules
}

\author{
D Santos Ornellas, R Grozovsky, R C Goldenberg, D P Carvalho, \\ P Fong ${ }^{1}$, W B Guggino ${ }^{1}$ and $M$ Morales
}

Instituto de Biofísica Carlos Chagas Filho, Universidade Federal do Rio de Janeiro, RJ, Brazil, CEP 21949-900

${ }^{1}$ Department of Physiology of the Johns Hopkins University School of Medicine, Baltimore, Maryland, 21205, USA

(Requests for offprints should be addressed to M M Morales, Instituto de Biofísica Carlos Chagas Filho-UFRJ, CCS- Bloco G, 21949-900 Rio de Janeiro, RJ, Brasil; Email: mmorales@ biof.ufrj.br)

\begin{abstract}
Thyroid hormones has its main role in controlling metabolism, but it can also modulate extracellular fluid volume (ECFV) through its action on the expression and activity of $\mathrm{Na}^{+}$transporters. Otherwise, chloride is the main anion in the ECFV and the influence of thyroid hormones in the regulation of chloride transporters is not yet understood. In this work, we studied the effect of thyroid hormones in the expression of $\mathrm{ClC}-2$, a cell volume-, $\mathrm{pH}-$ and voltagesensitive $\mathrm{Cl}^{-}$channel, in rat kidney. To analyze the modulation of $\mathrm{ClC}-2$ gene expression by thyroid hormones, we used hypothyroid (Hypo) rats with or without thyroxine $\left(\mathrm{T}_{4}\right)$ replacement and hyperthyroid (Hyper) rats as our experimental models. Total RNA was isolated and the expression of $\mathrm{ClC}-2$ mRNA was evaluated by a ribonuclease protection assay, and/or semi-quantitative
\end{abstract}

RT-PCR. Renal ClC-2 expression decreased in Hypo rats and increased in Hyper rats. In addition, semiquantitative RT-PCR of different nephron segments showed that these changes were due exclusively to the modulation of ClC-2 mRNA expression by thyroid hormone in convoluted and straight proximal tubules. To investigate whether thyroid hormones action was direct or indirect, renal proximal tubule primary culture cells were prepared and subjected to different $\mathrm{T}_{4}$ concentrations. ClC-2 mRNA expression was increased by $T_{4}$ in a dose-dependent fashion, as analyzed by RT-PCR. Western blotting demonstrated that $\mathrm{ClC}-2$ protein expression followed the same profile of mRNA expression.

Journal of Endocrinology (2003) 178, 503-511

\section{Introduction}

Chloride is the most abundant anion in the glomerular ultrafiltrate and its reabsorption along the nephron can occur through either paracellular or transcellular pathways. Several different proteins expressed in the renal tubule cells, including chloride channels, are responsible for the transcellular $\mathrm{Cl}^{-}$transport (Aronson \& Giebisch 1998). In this report we examine $\mathrm{ClC}-2$ regulation by thyroid hormones as well as the participation of $\mathrm{ClC}-2$ in chloride transport along the rat nephron.

ClC-2 belongs to the $\mathrm{ClC}$ family of voltage-gated chloride channels. Several members of the $\mathrm{ClC}$ family are involved in human hereditary diseases (Waldegger \& Jentsch 2000). In both rats and humans, ClC-2 is normally expressed in many cells, including those constituting the renal epithelium. Membrane hyperpolarization, changes in cellular volume, extracellular $\mathrm{pH}$ and intracellular chloride concentration (Stephen \& Klip 1995, Fritsch \& Edelman 1997, Jordt \& Jentsch 1998, Furukawa et al. 1999) all regulate the gating of ClC-2. Murray et al. (1995), suggested an involvement of $\mathrm{ClC}-2$ in the fetal development of the rat lung. The high levels of mRNA found in the kidney indicate that this channel may be important for $\mathrm{Cl}^{-}$reabsorption along the nephron (Ornellas et al. 2002).

It is known that hormones that are involved in extracelullar fluid volume (ECFV) regulation can modulate sodium chloride transport along the nephron. Two wellunderstood examples of hormones that regulate ECFV are atrial natriuretic factor (ANF) and aldosterone. ANF increases urinary sodium excretion by inhibiting sodium transporters in nephron segments, especially those of the inner medullary collecting ducts (Light et al. 1999). Aldosterone, another hormone important in regulation of ECFV, acts to increase sodium chloride reabsorption, primarily in the collecting ducts (Masilamani et al. 1999). Besides the classic hormones, other hormones can modulate renal function. For example, the thyroid hormones, triiodothyronine $\left(\mathrm{T}_{3}\right)$ and $\mathrm{T}_{4}$ (thyroxine), affect both renal morphology and function. They are required for kidney growth and development, and thyroid deficiency results in decreased renal plasma flow and glomerular 
filtration rate, as well as in impaired urinary concentration and dilution (Katz et al. 1985). In hyperthyroidism, decreased distal tubule delivery of chloride has been observed in the kidney (Shirota et al. 1992). The fractional excretion of sodium and chloride in the hypothyroid (Нypo) patients was significantly higher than that in the controls patients (Liu et al. 1990). Hypo patients have also a decrease in glomerular filtration rate and renal plasma flow that are completely reversed by $\mathrm{T}_{4}$ administration (Capasso et al. 1999); on the other hand, hyperthyroid (Hyper) subjects exhibit a significant increase in both parameters (Capasso et al. 1999). In addition, thyroid hormones can modulate the $\mathrm{Na}^{+} / \mathrm{K}^{+}$ATPase (Stephen \& Klip 1995) and activity of the $\mathrm{Na}^{+} / \mathrm{H}^{+}$exchanger, mostly in the proximal tubule (Morales et al. 1997). Furthermore, thyroid hormones alter not only sodium transport suggesting their importance in renal transport dynamism. In Hypo rats, for example, increased sodium and bicarbonate excretion rates were observed in urine compared with control animals. This change is probably related to the modulation of $\mathrm{Na}^{+} / \mathrm{H}^{+}$exchanger by thyroid hormone, mainly in proximal tubules (Kumar \& Prasad 2002). It was also suggested the thyroid hormones activate calcium reabsorption in proximal tubules via the $\mathrm{Na}^{+} / \mathrm{Ca}^{2+}$ exchanger through a cAMP-dependent pathway (Kumar \& Prasad 2002).

In a recent publication, we showed the expression of ClC-2 mRNA in all nephron segments except cortical and outer medullary collecting ducts and its modulation by aldosterone in cortical and medullary thick ascending limbs of Henle's loop (HL), indicating a possible role of this channel in the chloride transport in the kidney (Ornellas et al. 2002). It was also demonstrated that ClC-2 mRNA expression is decreased in the absence of arginine vasopressin in Brattleboro rats. Here, based on the clear effect of thyroid hormones in renal transport, we evaluate the action of this hormone on $\mathrm{ClC}-2$ expression in rat kidney, and in so doing, provide insight into the role of these channels in $\mathrm{Cl}^{-}$transport along the nephron.

\section{Materials and Methods}

\section{Animal preparation}

The Ethics Committee from The Biophysics Institute, Federal University of Rio de Janeiro, previously approved all procedures and protocols using animals mentioned in this manuscript. Male adult Wistar rats (weight of 200$250 \mathrm{~g}$, from Laboratório de Fisiologia Endócrina, Instituto de Biofisica Carlos Chagas Filho, Universidade Federal do Rio de Janeiro) were kept in a room with a controlled lighting (12 h light:12 h darkness, lights on at $0800 \mathrm{~h}$, off at $2000 \mathrm{~h}$ ) and temperature $\left(23-27^{\circ} \mathrm{C}\right)$. The control group had free access to food and tap water until the time of the experiment. Hypothyroidism was induced in the second group by the addition of $0.03 \%$ methimazole (Sigma Chemical Co., St Louis, MO, USA), an inhibitor of the synthesis of $T_{3}$ and $T_{4}$ (Ortiga-Carvalho et al. 1997), to the drinking water for 21 days (Hypo rats). Both groups received s.c. injections of saline during the last 10 days before killing. The third group was induced to hypothyroidism as described for the Hypo group, but also received daily s.c. injections of $\mathrm{T}_{4}$ (Sigma) at $1 \mu \mathrm{g} / 100 \mathrm{~g}$ body weight $(\mathrm{BW})$ during the 10 days before killing (Hypo $+\mathrm{T}_{4}$ rats). Hyperthyroidism was induced by s.c. injections of $\mathrm{T}_{4}(10 \mu \mathrm{g} / 100 \mathrm{~g} \mathrm{BW})$ to normal animals for 10 days prior to killing (Hyper rats). All rats had unlimited access to standard rodent diet. The animals were killed by decapitation $18 \mathrm{~h}$ after the last injections and blood samples were then collected for hormonal evaluation (OrtigaCarvalho et al. 1997).

\section{Serum $T_{4}$ quantification}

Serum $\mathrm{T}_{4}$ was measured in whole plasma by a specific and highly sensitive RIA using specific antiserum (Kit Coat A Count; Diagnostic Products Corporation, Los Angeles, CA, USA), using a standard curve made with rat serum free of hormones.

\section{Primary cell culture of proximal tubules}

Proximal tubules were dissected from normal rats (weighing 250-300 g) by a modification of the method described by Toutain et al. (1991). Rats were anesthetized with pentobarbitone sodium $(5 \mathrm{mg} / 100 \mathrm{~g} \mathrm{BW}$ ) for all procedures involving surgery. The abdominal aorta of each animal was accessed and the left kidneys were perfused with salt solution $(1.4 \mathrm{mM} \mathrm{NaCl}, 0.5 \mathrm{mM} \mathrm{KCl}, 0.1 \mathrm{mM}$ $\mathrm{Na}_{2} \mathrm{PO}_{4} \cdot 8 \mathrm{H}_{2} \mathrm{O}, \quad 0.3 \mathrm{mM}$ sodium acetate, $0.12 \mathrm{mM}$ $\mathrm{NaSO}_{4}, 2 \cdot 5 \mathrm{mM} \mathrm{CaCl}_{2}, 1 \cdot 2 \mathrm{mM} \mathrm{MgSO}_{4}, 5 \mathrm{mM}$ HEPES, $5.5 \mathrm{mM}$ glucose). The left kidneys were dissected into fine transverse slices and incubated at $37^{\circ} \mathrm{C}$ for $30 \mathrm{~min}$ with salt solution containing $0 \cdot 125 \mathrm{mg} / \mathrm{ml}$ collagenase B (Sigma). The tissue was then transferred to Dulbecco's modified Eagle's medium and nutrient mixture F-12 Ham (DMEM/F-12, 1:1) (Sigma) and the proximal tubule micro-dissection was performed under stereoscopy. After dissection, approximately 80 segments of proximal tubules, each $2 \mathrm{~mm}$ long, were placed in DMEM/F-12 supplemented with $5 \mu \mathrm{g} / \mathrm{ml}$ insulin and $5 \mu \mathrm{g} / \mathrm{ml}$ transferrin (both from Gibco BRL, Grand Island, NY, USA), $10^{-7} \mathrm{M}$ hydrocortisone, $5 \mathrm{ng} / \mathrm{ml}$ sodium selenite, 25 $\mathrm{IU} / \mathrm{ml}$ penicillin and $25 \mu \mathrm{g} / \mathrm{ml}$ streptomycin (all from Sigma), as described by Toutain et al. (1991). The proximal tubules were attached to the bottoms of rat-tail collagen-coated, $20 \mathrm{~mm}$ plastic culture plates using fine needles and cultured in a humidified, $37^{\circ} \mathrm{C}, 5 \% \mathrm{CO}_{2}$ incubator. Tubules were cultured for $20-25$ days or until confluent (Toutain et al. 1991). 
At confluence, $\mathrm{T}_{4}$ was added to achieve $10^{-9}, 10^{-8}$ and $10^{-7} \mathrm{M}$ final concentrations. Control cells had no $\mathrm{T}_{4}$ added to the medium. Twenty-four hours after $\mathrm{T}_{4}$ exposure, total RNA was isolated and the RT-PCR was performed.

\section{Isolation of total RNA}

Total RNA was extracted from whole kidney and also from proximal tubule cell primary cultures with Trizol reagent (Gibco BRL) using a modification of the singlestep RNA isolation method developed by Chomczynski \& Sacchi (1998).

Isolation of mRNA from rat nephronal segments $(3 \mathrm{~mm}$ each) was performed as previously described (Morales et al. 2000).

\section{Ribonuclease protection assay (RPA)}

The ClC-2 probe, corresponding to nucleotides 345-960 of the $\mathrm{ClC}-2$ rat sequence, was described before (Morales et al. 2001). The pTRI-rat- $\beta$-actin or pTRI-rat-GAPDH (125 and $315 \mathrm{bp}$ respectively) (Ambion, Austin, TX, USA) was used as template to make probes for internal controls. Following the Maxscript Kit protocol (Ambion), all templates were transcribed in vitro in the presence of $\left[\alpha-{ }^{32} \mathrm{P}\right] \mathrm{UTP}, \quad 3000 \mathrm{Ci} / \mathrm{mmol}$ (Amersham, Arlington Heights, IL, USA) with RNA polymerase T7 to generate radiolabeled antisense RNA probes. Prior to use in the RPA (RPAII kit; Ambion), all probes were evaluated with $10 \mu \mathrm{g}$ yeast transfer RNA in the presence and absence of RNase $A$ and $T_{1}$, according to the manufacturer's instructions. The undigested $\mathrm{ClC}-2, \beta$-actin and GAPDH probes were 116, 63 and 91 nucleotides larger than the digested probes respectively. Total RNA $(30 \mu \mathrm{g})$ from rat renal tissue was mixed with each radiolabeled antisense probe $\left(1 \times 10^{5}\right.$ c.p.m./sample $)$ along with $\beta$-actin or GAPDH internal control probes and hybridized at $45{ }^{\circ} \mathrm{C}$ for $19 \mathrm{~h}$. Both RNase $\mathrm{A}$ and $\mathrm{T}_{1}$ (RPAII kit; Ambion) were used to treat the samples at $37^{\circ} \mathrm{C}$ for $30 \mathrm{~min}$. The protected fragments were separated electrophoretically on $9 \mathrm{M}$ urea gels containing $50 \mathrm{~g} / 1$ polyacrylamide. The samples were transferred to chromatography papers and exposed to $\mathrm{X}$-ray films with an intensifying screen at $-90^{\circ} \mathrm{C}$ prior to exposure. The density of the bands corresponding to the expected sizes of the probes was analyzed with the aid of Sigma Gel v1·1 software (Jandel Scientific, San Rafeal, CA, USA).

\section{RT-PCR}

To prepare first-strand deoxyribonucleic acid (cDNA), total RNA samples isolated from whole kidney, dissected renal segments and primary proximal tubule cell cultures were firstly primed with oligodeoxythymidilic primer and then reverse transcribed with SuperScript (Gibco BRL) at $37^{\circ} \mathrm{C}$ for $60 \mathrm{~min}$.

PCR amplification of the synthesized cDNA utilized the following reaction conditions: $0 \cdot 2 \mu \mathrm{M}$ of the primers, $0 \cdot 2 \mu \mathrm{M}$ of each deoxynucleotide triphosphate and $50 \mathrm{mM}$ $\mathrm{KCl}, 10 \mathrm{mM}$ Tris- $\mathrm{HCl}(\mathrm{pH} 9 \cdot 3)$ and $1.5 \mathrm{mM} \mathrm{MgCl}_{2}$ plus 2.5 U of Amplitaq (Perkin Elmer, Norwalk, CT, USA). Primers for ClC-2 (sense 5'-CTATGCCATCGCGTC


$3^{\prime}$ ) corresponding to nucleotides 345-362 and 943-960 of rat ClC-2 cDNA sequence (Thiemann et al. 1992) respectively, were synthesized. PCR cycling parameters were: 35 cycles of denaturation $\left(94^{\circ} \mathrm{C}, 1 \mathrm{~min}\right)$, annealing $\left(55^{\circ} \mathrm{C}, 1 \mathrm{~min}\right)$ and extension $\left(72^{\circ} \mathrm{C}, 1 \mathrm{~min}\right)$.

To detect ClC-2 mRNA expression along the rat nephron, procedures for dissection of nephron segments $(3 \mathrm{~mm}$ each) and reverse transcription of mRNA were followed as described previously (Katz et al. 1985). These experiments were performed at least seven to nine times for each segment dissected from different rats.

Semi-quantitative RT-PCR was used to compare the expression of $\mathrm{ClC}-2$ in each of the following nine groups: (i) glomeruli, (ii) proximal convoluted tubule (PCT), (iii) proximal straight tubule (PST), (iv) cortical and (v) medullary thick ascending limbs (cTAL and mTAL respectively), (vi) thin limbs of HL, and the (vii) cortical, (viii) outer and (ix) inner medullary collecting tubules (CCD, OMCD and IMCD respectively) dissected from the following groups of rats: control, Hypo, Hypo $+\mathrm{T}_{4}$ and Hyper. PCR conditions were the same as those described above, with the addition of rat $\beta$-actin primers (sense 5'-TATGCCAACACAGTGCTGTCTGG-3' and antisense 5'-AAGAAAGCAAGACAGTGATTGTG-3', corresponding to nucleotides 2762-2794 and 2965-2997 of the rat $\beta$-actin gene and amplifying a predicted internal control product of $226 \mathrm{bp}$ ) to the same RT-PCR reaction tubes. The PCR products were separated using 1.5\% agarose gel electrophoresis. $\mathrm{ClC}-2$ and $\beta$-actin bands from the same sample were densitometrically analyzed and normalized by dividing the $\mathrm{ClC}-2$ values by the corresponding $\beta$-actin values.

The same technique was also used to compare the expression of $\mathrm{ClC}-2$ in both control and $\mathrm{T}_{4}$-treated primary proximal tubule cell cultures. $\mathrm{T}_{4}$ (Sigma) was added at different concentrations $\left(10^{-9}, 10^{-8}\right.$ and $\left.10^{-7} \mathrm{M}\right)$ in the test cultures.

The semi-quantitative method of RT-PCR was validated in preliminary experiments as described before (Ornellas et al. 2002). The PCR conditions were the same as described in previous work (Ornellas et al. 2002).

\section{Western blot analysis}

Expression of ClC-2 protein in whole rat kidney from control, Hypo, Hypo $+\mathrm{T}_{4}$ and Hyper groups was assessed 
and compared by immunoblotting using an antibody directed toward a synthetic peptide corresponding to amino acids 888-906 of the rat ClC-2 (Sigma). Kidneys from all rat groups were homogenized and the protein was obtained as described before (Park et al. 2001) and the membrane proteins $(100 \mu \mathrm{g} / \mathrm{lane})$ were subjected to $70 \mathrm{~g} / 1$ SDS-PAGE and transferred to $0.45 \mu \mathrm{m}$ Immobilon-NC nitrocellulose membranes (Sigma). We used the rabbit anti-ClC-2 antibody (1:300 dilution) diluted in Tris-buffered saline-Tween solution $(136 \cdot 8 \mathrm{mM}$ $\mathrm{NaCl}, 74 \cdot 5 \mathrm{mM} \mathrm{KCl}, 24 \cdot 8 \mathrm{mM}$ Tris base, $\mathrm{pH} 7 \cdot 4,0 \cdot 5 \%$ Tween 20) containing $30 \mathrm{~g} / \mathrm{l}$ non-fat milk, at room temperature for $1 \mathrm{~h}$. Sequential incubation was performed with a secondary antibody goat anti-rabbit $\operatorname{IgG}(\mathrm{H}+\mathrm{L})$ for alkaline phosphatase $(1: 1000)$. The $\mathrm{ClC}-2$ protein bands were detected using an alkaline solution $(100 \mathrm{mM} \mathrm{NaCl}$, $5 \mathrm{mM} \mathrm{MgCl} 2,100 \mathrm{mM}$ Tris, $\mathrm{pH} 9 \cdot 5), 75 \mathrm{mg} / \mathrm{ml}$ nitroblue tetrazolium chloride (NBT) and $50 \mathrm{mg} / \mathrm{ml}$ 5-bromo4-chloro-3-indolylphosphate $p$-toluidine salt (BCIP) (all from Life Technologies, Rockville, IL, USA) for $5 \mathrm{~min}$. As an internal control, the same experiment was performed in the absence of rabbit anti-ClC-2. In this condition, no bands were detected, suggesting that there was not any non-specific binding.

\section{Alkaline phosphatase assay}

To validate that primary cultures indeed were derived from proximal tubules, alkaline phosphatase activity was compared with that measured in rat kidney cortex homogenate as described before (Fine \& Sakhrani 1997). After confluence, cells in the primary cell culture were lysed with a hypertonic solution $(250 \mathrm{mM}$ sucrose, $1 \mathrm{mM}$ EDTA). Alkaline phosphatase was assayed in a reaction containing $7.5 \mathrm{mM}$-nitrophenyl phosphate, $5 \mathrm{mM}$ magnesium chloride, $0 \cdot 1 \%$ Triton $\mathrm{X}-100$ and $5 \mathrm{mM}$ borate $(\mathrm{pH} 10 \cdot 5)$ (Edelman 1975). The reaction was stopped by the addition of $100 \mu 11000 \mathrm{mM} \mathrm{NaOH}$ and read at $425 \mathrm{~nm}$ (visible light) in a spectrophotometer (Pharmacia Biotech Ultrospec 1000; Cambridge, UK).

\section{Statistics}

Results are presented as means \pm S.E.M. One-way ANOVA followed by Newman-Keuls multiple comparison test was used to compare the changes in the mRNA expression of $\mathrm{ClC}-2$. Differences were assumed to be significant when $P \leq 0 \cdot 05$.

\section{Results}

\section{Quantification of serum $T_{4}$}

For the control group, the mean level of $\mathrm{T}_{4}$ was $44 \pm 3.7 \mathrm{nM}$, whereas the Hypo group presented undetected levels of serum $\mathrm{T}_{4}(n=10)$. The Hypo $+\mathrm{T}_{4}$ group showed normal serum $\mathrm{T}_{4}(35 \pm 6 \cdot 3 \mathrm{nM})(n=10)$. Treatment of normal animals with supraphysiological doses of $\mathrm{T}_{4}$ for 10 days (Hyper) resulted in a significant increase in serum thyroid hormone levels to $119 \pm 10 \mathrm{nM})$, about $2 \cdot 7$-fold $(n=10$ and $P<0 \cdot 05)$.

\section{Quantification of ClC-2 mRNA expression in different groups}

Here, we used an RPA to test and quantify the influence of thyroid hormone on $\mathrm{ClC}-2 \mathrm{mRNA}$ expression in the kidney. A $615 \mathrm{bp}$ fragment corresponding to $\mathrm{ClC}-2$ was detected in RNA isolated from total rat kidney from the control animals as well as three experimental groups: Hypo, Hypo $+\mathrm{T}_{4}$ and Hyper. The resultant bands were then subjected to densitometric analysis $(n=9)$. GAPDH signal measurements, which were hybridized in the same reaction, were then used as an internal control, against which the $\mathrm{ClC}-2$ measurements were normalized. Figure 1 expresses the mean densitometric values ratio between $\mathrm{ClC}-2$ and $\mathrm{GAPDH}$ in all the four groups studied. Compared with the control group, renal $\mathrm{ClC}-2$ mRNA expression in Hypo rats decreased 40\% $(P<0 \cdot 05)$, whereas it increased significantly by $63 \%$ in Hyper rats $(P<0 \cdot 05)$. $\mathrm{T}_{4}$ administration to Hypo rats $\left(\mathrm{Hypo}+\mathrm{T}_{4}\right)$ restored the expression of renal $\mathrm{ClC}-2 \mathrm{mRNA}$ to levels comparable with those observed for control rats.

\section{Quantification of ClC-2 $m R N A$ along the nephron by RT-PCR}

In previous experiments, we detected the expression of ClC-2 mRNA in all nephron segments, except in the CCD and the OMCD (Ortiga-Carvalho et al. 1997). Indeed, in the present study, RT-PCR revealed bands of the expected size, $615 \mathrm{bp}$, in most nephron segments. Figure 2 summarizes the ratios between the mean densitometric values for $\mathrm{ClC}-2$ and $\beta$-actin for different dissected nephron segments taken from the four experimental groups. Relative to controls, this ratio increased by $47 \%$ in PCTs of Hyper rats. Hypo animals showed a decrease in PCT ClC-2 mRNA expression of $49 \%(n=6$, $P<0 \cdot 05$; Fig. 2). In PSTs, mRNA expression of $\mathrm{ClC}-2$ mRNA increased by $56 \%$ in Hyper animals and decreased by $49 \cdot 3 \%$ in Hypo rats related to control $(n=6, P<0 \cdot 05$; Fig. 2). In both segments, PST and PCT, the expression of mRNA of ClC-2 returned to the control values in Hypo $+\mathrm{T}_{4}$ rats. None of the following segments showed variation in $\mathrm{ClC}-2$ mRNA expression between groups: glomeruli $(n=5$, Fig. 2), HL $(n=5$, Fig. 2$), \operatorname{mTAL}(n=5$, Fig. 2), cTAL ( $n=5$, Fig. 2) and IMCD ( $n=5$, Fig. 2). Consistent with our previous observations, ClC-2 mRNA expression was detected in neither $\operatorname{CCD}(n=4$, Fig. 2$)$ nor $\operatorname{OMCD}(n=4$, Fig. 2). 

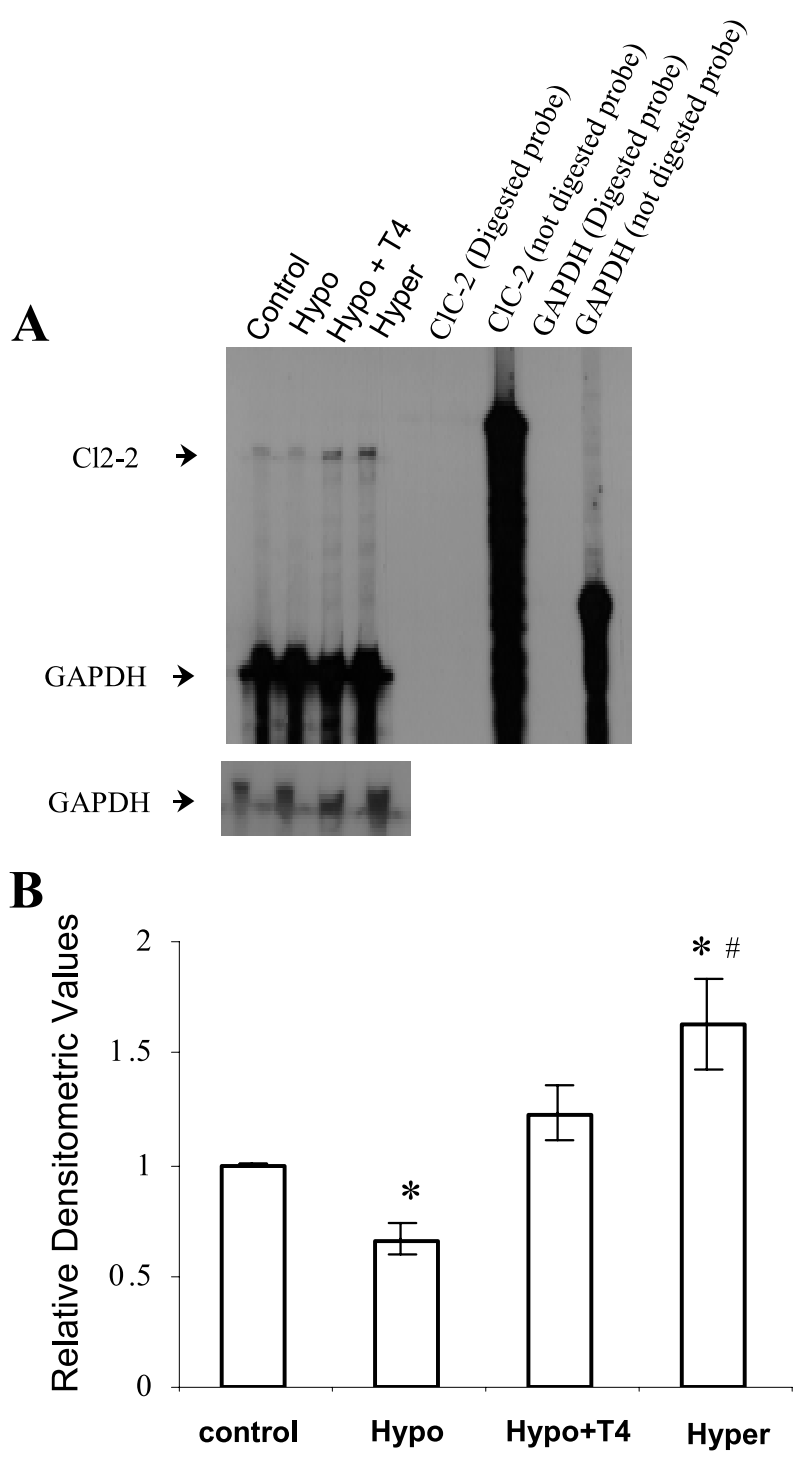

Figure $1 \mathrm{ClC}-2$ mRNA detection by RPA assay of transcripts performed on total RNA extracted from kidneys of rats under different experimental conditions. (A) ClC-2 (not digested probe): $\mathrm{ClC}-2$ probe not digested with $\mathrm{RNase}$. ClC-2 (Digested probe): ClC-2 probe digest with RNase. GAPDH (not digested probe): GAPDH probe not digest with RNase. GAPDH (Digested probe): GAPDH probe digest with RNase. The protected fragments of 615 and 317 bp correspond to $\mathrm{ClC}-2$ and GAPDH respectively. Control, (Hypo): hypothyroid rats, (Hypo+T4): hypothyroid rats treated with physiological doses of $\mathrm{T}_{4}(1 \mu \mathrm{g} / 100 \mathrm{~g} \mathrm{BW} / 10$ days $)$, (Hyper): normal rats treated with high doses of $\mathrm{T}_{4}(10 \mu \mathrm{g} / 100 \mathrm{~g}$ $\mathrm{BW} / 10$ days). In the lower panel is shown a less exposed autoradiographic film containing the GAPDH bands, from which the densitometric values were used to normalize the correspondent $\mathrm{ClC}-2$ values. (B) Values obtained for the ratio between the densitometric analyses of the specific activity of the ClC-2/GAPDH bands obtained from four RPA experiments performed from nine different rats in each group. The results are expressed as means \pm S.E.M and values are relative to control. *Statistically different from control group. ${ }^{\#}$ Statistically different from Hypo+T4 group.
ClC-2 $m R N A$ expression modulation by thyroid hormone in proximal tubule primary culture cells

Means of densitometric values $(n=3)$ showed an increase in ClC-2 mRNA expression after $\mathrm{T}_{4}$ administration in a dose-dependent manner. Control cell mRNA expression was taken as $100 \% . \mathrm{T}_{4}$ added to cell culture medium, at concentrations of $10^{-9}, 10^{-8}$ and $10^{-7} \mathrm{M}$, significantly increased rat renal primary culture proximal tubule cell ClC-2 mRNA respectively, by 37,79 and $100 \%$ of control levels $(n=3, P<0 \cdot 05)$ (Fig. 3).

\section{Western blot analysis of $\mathrm{ClC}-2$ protein expression in rat} kidney

The mRNA levels do not necessarily correlate directly with the amount of protein expression. To examine ClC-2 expression in the four different experimental groups, we performed Western blot analysis using $100 \mu \mathrm{g}$ protein for each sample group $(n=5)$. A fragment of $90 \mathrm{kDa}$, corresponding to the predicted molecular mass of $\mathrm{ClC}-2$ protein, was detected in all experimental groups (Murray et al. 1995). Comparisons of renal ClC-2 protein expression between groups were related to control. Renal ClC-2 protein expression decreased significantly by $62 \%$ in the Hypo group whereas it significantly increased by $49 \cdot 3 \%$ in the Hyper group $(P<0 \cdot 05)$. In the Hypo+ $\mathrm{T}_{4}$ group, ClC-2 expression was restored to control levels (Fig. 4).

\section{Discussion}

ClC-2 was originally isolated from a rat heart and brain cDNA library. Its wide expression in diverse organs and epithelia has pointed to function as a housekeeping gene (Waldegger \& Jentsch 2000). We note, however, that ClC-2 is also highly expressed in the kidney (Murray et al. 1995) and that its role in this organ is not completely understood. Our group has previously shown that $\mathrm{ClC}-2$ is distributed in all nephron segments except in cortical and outer medullary collecting ducts (Ornellas et al. 2002) supporting its possible importance in the kidney. The renal ClC-2 is modulated by aldosterone (Ornellas et al. 2002). Aldosterone plays an important role in ECFV regulation (Thiemann et al. 1992, Nasemann \& Horster 1998), and its modulation of $\mathrm{ClC}-2$ is pronounced in the thick ascending limbs of HL, suggesting a possible physiological role for $\mathrm{ClC}-2$ in ECFV regulation. Because chloride is the main sodium co-ion, it is reasonable to postulate that hormones involved in ECFV regulation via an action on renal sodium transporters may also modulate renal chloride transporters. Besides the classic hormones, such as aldosterone, that are known to be involved in the regulation of $\mathrm{NaCl}$ transport by the kidney (Masilamani et al. 1999), 

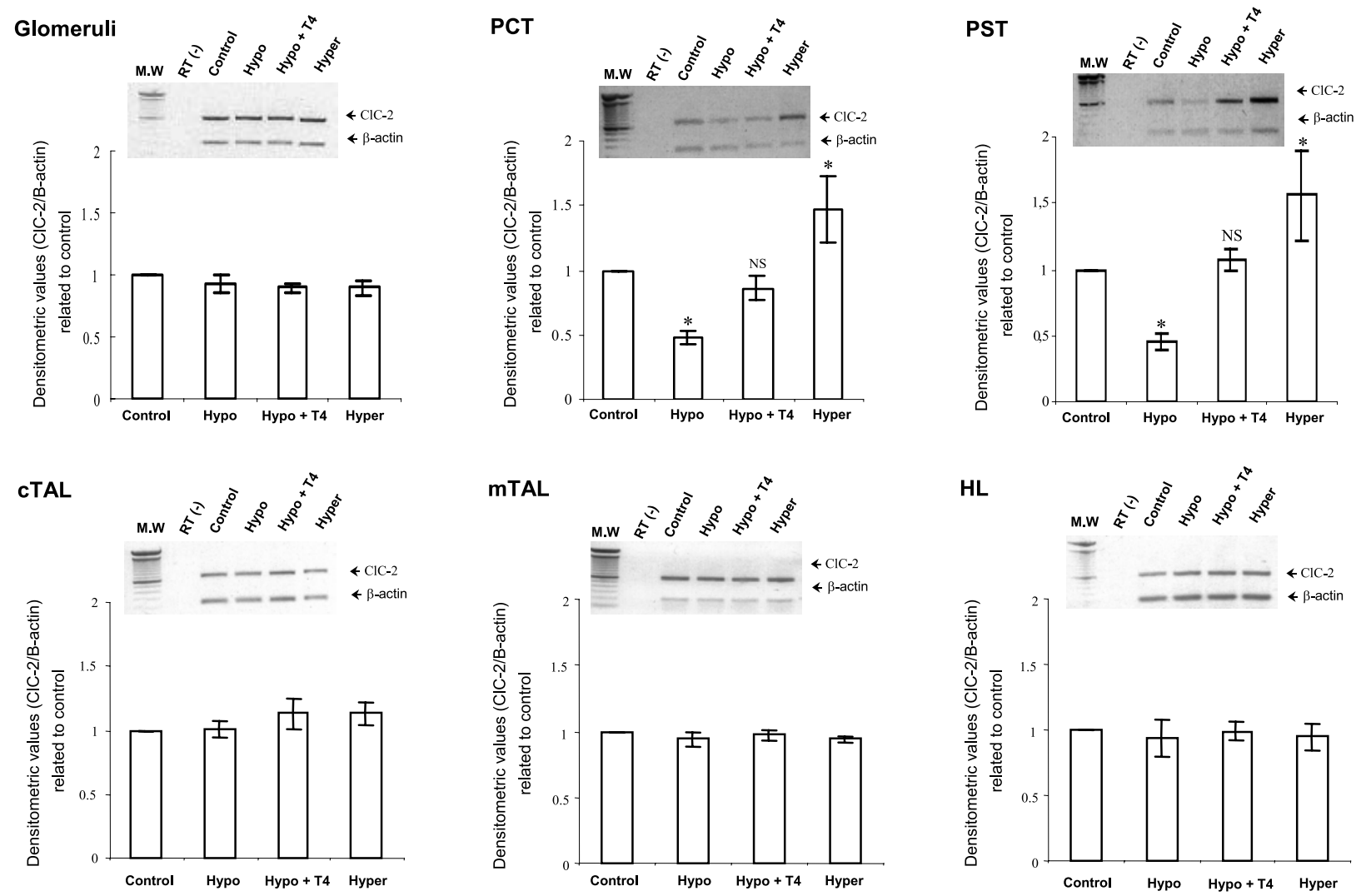

OMCD
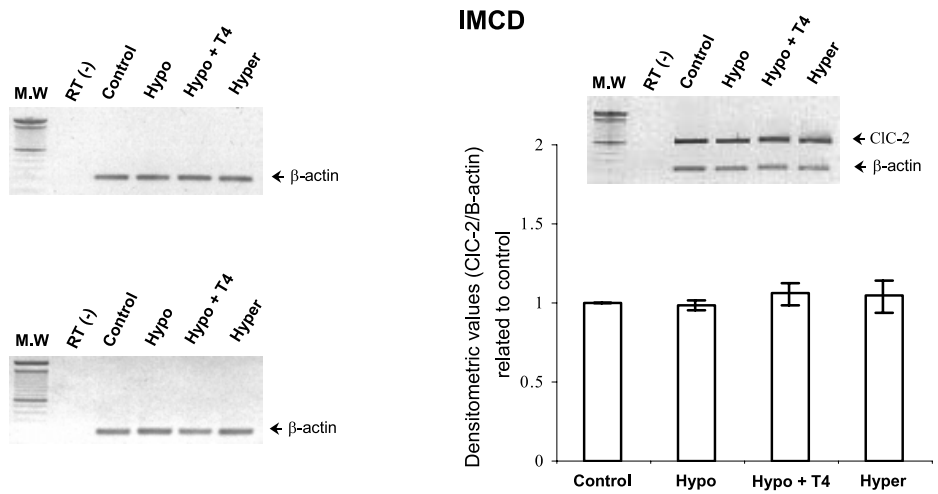

Figure 2 Relative expression of ClC-2 mRNA in different nephron segments obtained by amplification of ClC-2 and $\beta$-actin by semiquantitative RT-PCR. RT( - ): negative control using RNA from each segment in the absence of reverse transcriptase; M.W: 100 bp ladder (Gibco BRL). Different nephron segments were stereoscopically dissected and assayed by semi-quantitative RT-PCR. The respective graphics represents the means \pm S.E.M. for the ratio between the densitometric values of ClC- 2 and $\beta$-actin bands obtained in RT-PCR experiments. ${ }^{*} P \leq 0.05$ at minimum vs each other in each case. Glomeruli $(n=5), \operatorname{PCT}(n=7), \operatorname{PST}(n=7), \mathrm{cTAL}(n=5), \mathrm{mTAL}(n=5), \mathrm{HL}$ $(n=5)$, OMCD $(n=4), \operatorname{CCD}(n=4)$, IMCD $(n=5)$. Control, hypothyroid (Hypo) rats, (Hypo+T4) hypothyroid rats treated with physiological doses of $\mathrm{T}_{4}\left(1 \mu \mathrm{g} / 100 \mathrm{~g}\right.$ BW/10 days) and normal rats treated with high doses of $\mathrm{T}_{4}(10 \mu \mathrm{g} / 100 \mathrm{~g}$ BW/10 days) (Hyper).

other hormones, such as thyroid hormone, are also capable of regulating the ECFV via modulation of nephron ion and fluid transport. Thyroid hormones has been shown to increase fluid reabsorption in rat proximal tubules (Capasso et al. 1999). Importantly, thyroid hormone modulates the expression of $\mathrm{Na}^{+} / \mathrm{K}^{+}$ATPase mRNA and protein, and hence regulates the activity of this critical component of renal sodium transport (McDonough et al. 1988, Azuma et al. 1993, Barlet et al. 1995). In proximal tubule, thyroid hormone acts on the $\mathrm{Na}^{+} / \mathrm{H}^{+}$exchanger to change 


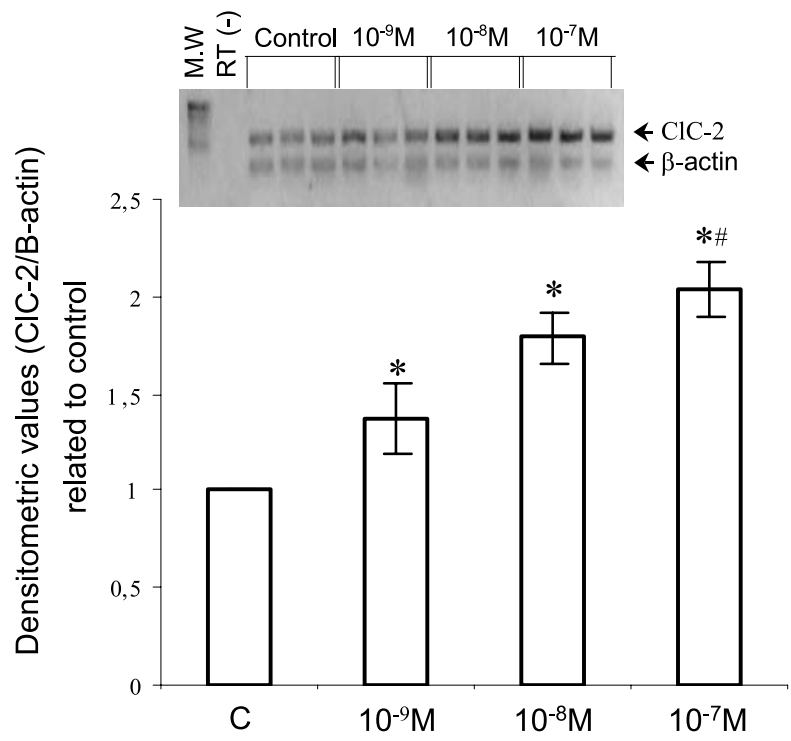

Figure 3 Effect of different concentrations of $T_{4}$ on mRNA expression of $\mathrm{ClC}-2$ in proximal tubule primary cultured cells using semi-quantitative RT-PCR. *Statistically different from control $(n=3$, $P<0.05) .{ }^{\#}$ Statistically different from control and $10^{-9} \mathrm{M}$ groups $(n=3, P<0 \cdot 05)$. In all experiments the ClC-2 expression was expressed as the ratio between $\mathrm{ClC}-2(615 \mathrm{bp})$ and the corresponding $\beta$-actin (125 bp) band intensity; both originated in the same reaction tube. The graphics represent the mean of the three independent experiments. Insert: M.W, molecular weight (lane 1), RT ( - ) (lane 2), Control, experimental control (lanes 3-5), cells treated with $10^{-9} \mathrm{M}$ (lanes 6-8), $10^{-8} \mathrm{M}$ (lanes 9-11) and $10^{-7} \mathrm{M}$ (lanes $\left.12-14\right) \mathrm{T}_{4}$.

intratubular acidification dynamics (Morales et al. 1997). Alteration of renal function in hyperthyroidism decreases distal tubule delivery of chloride (Shirota et al. 1992). Thus, the notion that thyroid hormones acts by regulating the expression of different sodium and chloride transporters in the kidney is plausible in the light of its involvement in increasing renal fluid reabsorption (Edelman 1975).

We report here our observation that thyroid hormones modulates $\mathrm{ClC}-2$ in the rat kidney. The modulation was detectable in total rat kidney, and our RPA results showed a decrease of $\mathrm{ClC}-2$ mRNA expression in Hypo rats compared with control levels. Hyper rats that received supra-physiological doses of $\mathrm{T}_{4}$, had their mRNA expression increased by 1.5 -fold relative to control levels. Hypo rats with hormone replacement at physiological doses showed expression of ClC-2 mRNA at levels comparable with those measured in control rats. The same pattern of expression was observed for $\mathrm{ClC}-2$ protein in rat kidney between the studied groups. More detailed analysis, using RT-PCR on isolated nephronal segments as well as cultured proximal tubule cells, showed that the results of RPA were attributable to the modulation of $\mathrm{ClC}-2$

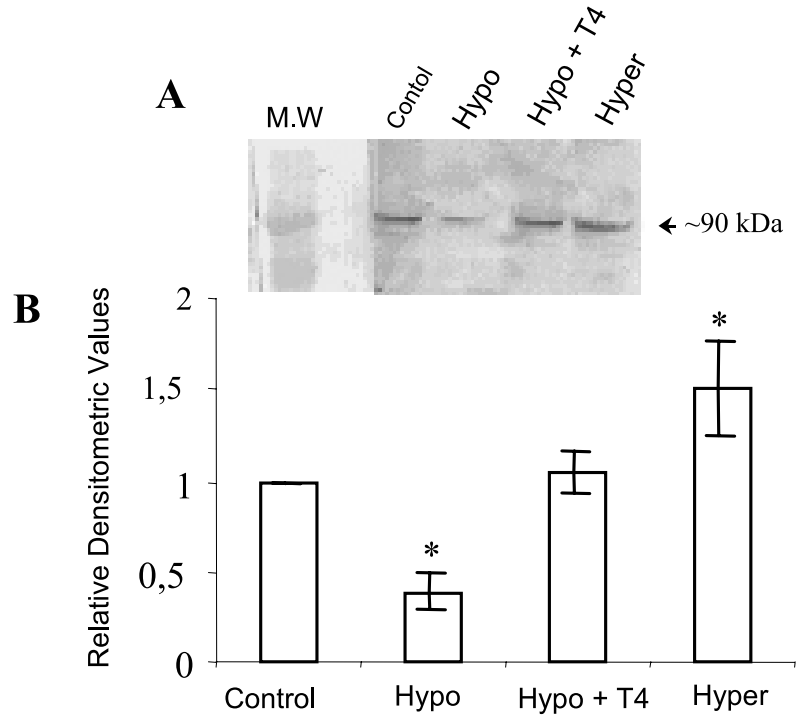

Figure 4 Expression of $\mathrm{ClC}-2$ protein in total membranes of renal tissue of rats subjected to different experimental conditions. The results are expressed as means \pm S.E.M. Values are for the densitometric analysis of the $\mathrm{ClC}-2$ protein bands obtained in the immunoblotting experiments $(n=5 ; P<0 \cdot 05)$. *Statistically different from control. Insert: a representative immunoblot for $\mathrm{ClC}-2$ in membrane extracts prepared from rat kidneys: control, hypothyroid rats (Hypo), hypothyroid rats treated with physiological doses of $\mathrm{T}_{4}(1 \mu \mathrm{g} / 100 \mathrm{~g} \mathrm{BW} / 10$ days) (Hypo+T4) and normal rats treated with high doses of $\mathrm{T}_{4}(10 \mu \mathrm{g} / 100 \mathrm{~g}$ BW/10 days) (Hyper). One hundred micrograms of proteins were loaded into each lane. The blot was probed with the anti-ClC-2 antibody $(1: 1000)$ and the signals were obtained after incubation with NBT and $50 \mathrm{mg} / \mathrm{ml} \mathrm{BCIP}$.

message only in rat PCT and PST respectively. The specific thyroid hormones action in proximal tubules is consistent with the fact that this nephron segment has the greatest density of thyroid hormone receptors and is thus more responsive to the action of thyroid hormones (Barlet et al. 1995). This characteristic of the proximal tubule may be due to its high metabolic activity, an attribute that is necessary for its role in transporting ions and hence $70 \%$ of the total filtered fluid (Capasso et al. 1999).

We noted a statistically significant dose-dependent increase in ClC-2 mRNA expression in $\mathrm{T}_{4}$-treated rat proximal tubule primary cell cultures. This modulation indicates a direct action of $\mathrm{T}_{4}$ on $\mathrm{ClC}-2$ mRNA expression in PST and PCT epithelial cells in rat kidney, segments where ClC-2 mRNA occurred in high abundance. However, our findings do not rule out an indirect action of thyroid hormone on $\mathrm{ClC}-2 \mathrm{mRNA}$ expression in proximal tubules. In other words, thyroid hormones could be inducing the release of other hormones that in turn affect $\mathrm{ClC}-2$ mRNA expression. For example, in Hypo rats, the reduction of plasma renin activity consequently decreases plasma concentrations of angiotensin I and II, as 
well as aldosterone (Asmah et al. 1998, Park et al. 2001). Therefore, the renin-angiotensin system could be modulating the expression of many genes, such as $\mathrm{ClC}-2$, under the influence of thyroid hormone (Stephen \& Klip 1995).

That $\mathrm{ClC}-2$ protein expression in rat kidney follows the same pattern as found for ClC-2 mRNA confirms the physiological importance of $\mathrm{ClC}-2$ in this organ. Our findings also support previous work showing that the lack or decrease of plasma thyroid hormones leads to a diminished expression (Stephen \& Klip 1995) and activity of $\mathrm{Na}^{+}$and $\mathrm{Cl}^{-}$transporters (Stephen \& Klip 1995), as well as the prediction that hormonal replacement with $\mathrm{T}_{3}$ or $\mathrm{T}_{4}$ leads to normalization or even an increase in fluid reabsorption, depending on the dose, in the proximal tubule of rat nephrons. Taken together, our findings lead us to suggest the involvement of $\mathrm{ClC}-2$ in the chloride transport modulated by thyroid hormones in rat renal proximal tubules.

\section{Acknowledgements}

The present work was supported by grants from NIH (HL47122 and DK 32753), Fundação José Bonifácio (FUJB), Fundação Carlos Chagas Filho de Amparo à Pesquisa do Estado do Rio de Janeiro (FAPERJ), Fundação de Amparo à Pesquisa do Estado de São Paulo (FAPESP) and Conselho Nacional de Desenvolvimento Científico e Tecnológico (CNPq).

\section{References}

Aronson PS \& Giebisch G 1998 Mechanisms of chloride transport in the proximal tubule. American Journal of Physiology. Renal Physiology 283 F189-F192.

Asmah BJ, Wan Nazaimoon WM, Tan T \& Khalid BAK 1998 Plasma renin and aldosterone in thyroid diseases. Hormone and Metabolic Research 29 590-593.

Azuma KK, Hensley CB, Tang MJ \& McDonough A 1993 Thyroid hormone specifically regulates skeletal muscle $\mathrm{Na}^{+}-\mathrm{K}^{+}$ATPase $\alpha 2-$ and 32 -isoforms. American Journal of Physiology. Cell Physiology 275 C790-C798.

Barlet C, Ben Abdelkhalek M \& Doucet A 1995 Sites of thyroid hormone action on $\mathrm{Na}^{+}-\mathrm{K}^{+}$ATPase along the rabbit nephron. Pflügers Archiv 405 52-58.

Capasso G, De Tommaso G, Pica A, Anastasio P, Capasso J, Kinne R \& De Santo NG 1999 Effects of thyroid hormones on heart and kidney functions. Mineral and Electrolyte Metabolism 25 57-74.

Chomczynski P \& Sacchi N 1998 Single-step method of RNA isolation by acid guanidinium thiocyanate-phenol-chloroform extraction. Annals of Biochemistry 172 157-159.

Edelman IS 1975 Thyroidal regulation of renal energy metabolism and (Na-K)-activated adenosine triphosphatase activity. Medical Clinics of North America 59 605-614.

Fine LG \& Sakhrani LM 1997 Proximal tubular cells in primary culture. Mineral and Electrolyte Metabolism 12 51-58.

Fritsch J \& Edelman A 1997 Modulation of the hyperpolarizationactivated $\mathrm{Cl}^{-}$current in human intestinal T94 epithelial cells by phosphorylation. Journal of Physiology 490 115-129.

Furukawa T, Ogura T, Katayama Y and Hiraoka M 1999 Characteristics of rabbit ClC-2 current expressed in Xenopus oocytes and its contribution to volume regulation. American Journal of Physiology. Cell Physiology 284 C500-C512.

Jordt SE \& Jentsch TJ 1998 Molecular dissection of gating in the ClC-2 chloride channel. EMBO Journal 16 1592-1592.

Katz AI, Emmanouel DS \& Lindheimer MD 1985 Thyroid hormone and the kidney. Nephron 15 223-249.

Kumar V \& Prasad R 2002 Molecular basis of renal handling of calcium in response to thyroid hormone status of rat. Biochimica et Biophysica Acta 24 331-343.

Light DB, Schwiebert EM, Karlson KH \& Stanton BA 1999 Atrial natriuretic peptide inhibits a cation channel in renal inner medullary collecting duct cells. Science 243 393-395.

Liu XM, Bai Y \& Guo ZS 1990 Study on urinary function and metabolism of water and electrolytes in primary hypothyroidism. Zhonghua Neike Zazhi 29 299-302.

Masilamani S, Kim GH, Mitchell C, Wade JB \& Knepper MA 1999 Aldosterone-mediated regulation of EnaC alpha, beta, and gamma subunit proteins in rat kidney. Journal of Clinical Investigation 104 R19-R23.

McDonough AA, Brown TA, Horowitz B, Chiu R, Schlotterbeck, Bowen J \& Schmitt 1988 Thyroid hormone coordinately regulates $\mathrm{Na}^{+}-\mathrm{K}^{+}$ATPase $\alpha$ - and $\beta$-subunit mRNA levels in kidney. American Journal of Physiology. Cell Physiology 254 C323-C329.

Morales MM, Brucoli HCP, Malnic G \& Lopes AG 1997 Role of thyroid hormones in renal tubule acidification. Molecular and Cellular Biochemistry 154 18-21.

Morales MM, Capella MA, Sanches MV, Lopes AG \& Guggino WB 2000 Modulation of the mdr- $1 \mathrm{~b}$ gene in the kidney of rats subjected to dehydration or a high-salt diet. Pflügers Archiv 43 357-372.

Morales MM, Nascimento DS, Capella MA, Lopes AG \& Guggino WB 2001 Arginine vasopressin regulates CFTR and ClC-2 mRNA expression in rat kidney cortex and medulla. Pflügers Archiv 443 202-211.

Murray CB, Morales MM, Flotte TR, McGrath-Morrow AS \& Guggino WB 1995 ClC-2: a developmentally dependent chloride channel expressed in the fetal lung and downregulated after birth. American Journal of Respiratory Cell and Molecular Biology 12 597-604.

Nasemann J \& Horster MF 1998 Aldosterone induces chloride transport in the cortical collecting tubule. Journal of Developmental Physiology 9 528-537.

Ornellas DS, Nascimento DS, Christoph DH, Guggino WB \& Morales MM 2002 Aldosterone and high $\mathrm{NaCl}$ diet modulate $\mathrm{ClC}-2$ chloride channel gene expression in rat kidney. Pflügers Archiv 444 193-201.

Ortiga-Carvalho TM, Polak J, MaCann S \& Pazos-Moura CC 1997 Effect of thyroid hormones on pituitary neuromedin B and possible interaction between thyroid hormones and neuromedin B on thyrotropin secretion. Regulatory Peptides 78 48-53.

Park CW, Shin YS, Ahn SJ, Kim SY, Choi EJ, Chang YS \& Bang BK 2001 Thyroxine treatment induces upregulation of reninangiostensin-aldosterone system due to decreasing effective plasma volume in patients with primary myxoedema. Nephrology, Dialysis, Transplantation 7 1899-1907.

Shirota T, Shinoda T, Yamada T \& Aizawa T 1992 Alteration of renal function in hyperthyroidism: increased tubular secretion of creatinine and decreased distal tubule delivery of chloride. Metabolism 41 402-405.

Stephen EH \& Klip A 1995 Hormonal regulation of the $\mathrm{Na}^{+}-\mathrm{K}^{+}$ATPase: mechanisms underlying rapid and sustained changes in pump activity. American Journal of Physiology. Cell Physiology 279 C295-C311. 
Thiemann A, Gründer S, Pusch M \& Jentsch TJ 1992 A chloride channel widely expressed in epithelial and non-epithelial cells. Nature 357 58-70.

Toutain H, Vauclin-Jacques N, Fillastre JP \& Morin JP 1991 Biochemical, functional, and morphological characterization of a primary culture of rabbit proximal tubule cells. Experimental Cell Research 194 9-19.
Waldegger S \& Jentsch TJ 2000 From tonus to tonicity: physiology of CLC chloride channels. Journal of the American Society of Nephrology 11 1331-1339.

Received in final form 5 June 2003

Accepted 5 June 2003 